\title{
ANALISIS KADAR TIMBAL (Pb) PADA RAMBUT PEKERJA BENGKEL TAMBAL BAN DAN IKAN MAS DI SEPANJANG JALAN SOEKARNO-HATTA BANDAR LAMPUNG SECARA SPEKTROFOTOMETRI SERAPAN ATOM
}

\author{
Samsuar $^{1}$, M. Kanedi ${ }^{2}$, Sherly Pebrice ${ }^{3}$, Widhalita Ari $\mathbf{P}^{4}$ \\ ${ }^{1,3,4}$ Program Studi Farmasi UTB Lampung, ${ }^{2}$ Program Studi Biologi MIPA Unila \\ Email: mrsam_utb@yahoo.co.id
}

\begin{abstract}
Analysis of Content (Pb) in Hair Tire Repair Shop Workers and Golden Fish Along The Soekarno-Hatta Bandar Lampung with Atomic Absorption Spectrophotometry. Lead is often referred to as a lead or of lead, the metal is denoted by $\mathrm{Pb}$. Heavy metal lead can cause poisoning and accumulate in the human body. Process of entry into the body can lead through food and drink, the air and the penetration of the skin. Absorption through the skin may occur due to these compounds soluble in oils and fats. Lead through the air into the respiratory tract to be absorbed and binds to lung blood is then circulated to all the tissues and organs of the body, while by foods possible cause fish was foods source of protein had bepouled of lead. On the hair can be bound to sulfhydryl groups so that the lead content in the hair can be an indicator of lead contamination. This study aims to analyze the levels of lead in the hair tire repair shop workers and goldfish keep in along the Soekarno-Hatta Airport Lampung. Examination conducted quantitative analysis using Atomic Absorption Spectrophotometry. The determination of the concentration of lead in Atomic Absorption Spectrophotometry obtained linear regression equation of lead standard solution is y: $0.0100 x-0.00933$, the correlation coefficient $\left(r_{x, y}\right)$ of 0.999 . Lead provides maximum absorption at a wavelength of $283.3 \mathrm{~nm}$. The results showed that the positive tire repair shop workers have polluted lead. The highest lead level is $4.813 \mathrm{ppm}$ while the lowest lead content was $0.258 \mathrm{ppm}$. In fish gills and meat of goldfish the highest lead level ware 0.15878 and $0.1160 \mathrm{ppm}$ while the lowest lead content ware 0.1136 and $0.0539 \mathrm{ppm}$.
\end{abstract}

Keywords: Lead (Pb), Hair, fish, Atomic absorption spectrophotometry

\begin{abstract}
Abstrak: Analisis Kadar Timbal (Pb) Pada Rambut Pekerja Bengkel Tambal Ban dan Ikan Mas di Sepanjang Jalan Soekarno-Hatta Bandar Lampung secara Spektrofotometri Serapan Atom. Timbal sering disebut sebagai timah hitam atau plumbum, logam ini disimbolkan dengan $\mathrm{Pb}$. Timbal logam berat dapat menyebabkan keracunan dan terakumulasi dalam tubuh manusia. Proses masuknya timbal ke dalam tubuh dapat melalui makanan dan minuman, udara, dan penetrasi pada kulit. Penyerapan lewat kulit ini dapat terjadi disebabkan karena senyawa ini dapat larut dalam minyak dan lemak. Timbal melalui udara masuk ke saluran pernafasan akan terserap dan berikatan dengan darah paru-paru kemudian diedarkan ke seluruh jaringan dan organ tubuh, sedangkan lewat maknan dapat terjadi karena makana khusunya ikan sebagai sumber protein telah terpapar timbal. Pada rambut timbal dapat terikat pada gugus sulfhidril sehingga kandungan timbal pada rambut dapat dijadikan indikator pencemaran timbal. Penelitian ini bertujuan untuk menganalisis kadar timbal pada rambut pekerja bengkel tambal ban dan ikan mas yang dipelihra di sepanjang jalan Soekarno-Hatta Bandar Lampung. Pemeriksaan dilakukan secara analisis kuantitatif menggunakan Spektrofotometri Serapan Atom. Pada penetapan konsentrasi timbal secara Spektrofotometri Serapan Atom diperoleh persamaan regresi linier larutan standar timbal yaitu y : 0,0100x- 0,00933, koefisien korelasi $\left(\mathrm{r}_{\mathrm{x}, \mathrm{y}}\right)$ sebesar 0,999. Timbal memberikan serapan maksimum pada panjang gelombang $283,3 \mathrm{~nm}$. Hasil penelitian menunjukan bahwa pekerja bengkel tambal ban positif telah tercemar timbal. Kadar timbal tertinggi yaitu 4,813 ppm sedangan kadar timbal terendah $0,258 \mathrm{ppm}$. Pada insang dan daging ikan kadar tertinggi 0,15878 dan 0,1160 ppm, kadar terendah 0,11636 dan 0,0539 ppm.
\end{abstract}

Kata kunci: Timbal (Pb), Rambut, Ikan, Spektrofotometri Serapan Atom 
Udara bersih adalah udara yang cukup akan kebutuhan oksigen $\left(\mathrm{O}_{2}\right)$ yang dibutuhkan makhluk hidup untuk proses fisiologis normal. Di daerah perkotaan yang ramai, gas pencemar berasal dari asap kendaraan, gas buangan pabrik, pembangkit tenaga listrik, asap rokok dan sebagainya yang erat hubungannya dengan aktivitas kehidupan manusia (Darmono, 2009).

Pertambahan jumlah kendaraan bermotor sekarang yang sangat pesat memberikan dampak negatif bagi yang bekerja di pinggir jalan raya. Kendaraan bermotor merupakan penyumbang utama dari seluruh emisi racun di udara. Satu diantaranya emisi racun di udara adalah logam timbal. Polusi udara ini dapat menyebabkan penyakit jika terakumulasi terlalu lama dalam darah manusia (Ardyanto 2005).

Pada Rambut gugus sulfhidril dan disulfida dalam rambut mampu mengikat unsur runut yang masuk ke dalam tubuh dan terikat di dalam rambut. Senyawa sulfida mudah terikat oleh unsur runut, maka bila unsur runut masuk ke dalam tubuh, unsur runut tersebut akan terikat oleh senyawa sulfida dalam rambut (Pettrucci, 1982).

Pada ikan, logam berat terakumulasi ke dalam jaringan tubuh dengan beberapa jalan yaitu saluran pencernaan, pernapasan dan penetrasi melalui kulit di dalam tubuh. Proses akumulasi logam dalam jaringan terjadi setelah absorbsi logam dari air yang telah terkontaminasi melalui udara dan terbawa oleh air hujan. Bioakumulasi logam dalam jaringan ikan cukup bervariasi, bergantung pada jenis logam dan spesies ikan (Darmono, 1995).

Unsur timbal yang terabsorpsi baik langsung lewat udara atau maupun tidak langsung melalui makanan yang terpapar timbal (ikan dalam kolam) diangkut oleh darah ke seluruh organ tubuh, dimana terabsorpsi dalam tubuh dapat terikat dan merusak jaringan tubuh atau diekresikan melalui urin, feses, keringat, rambut dan kuku. Timbal dalam darah yaitu sebanyak 95\% terikat oleh eritrosit dan disebarkan ke seluruh jaringan tubuh dapat terdeposit pada jaringan lunak (sumsum tulang, sistem saraf, ginjal, dan hati) dan jaringan keras (tulang, gigi, kuku dan rambut). Unsur timbal dalam jaringan lunak bersifat toksik terhadap jaringan itu sendiri (Sudarmaji et al., 2006).

Sekitar 90\% timbal yang terserap oleh darah berikatan dengan sel-sel darah merah (Palar, 2008). Menurut WHO batasan kadar timbal pada darah yaitu di bawah $10 \mu \mathrm{g} / \mathrm{dL}$ (ppm) dikategorikan rendah, dan di atas $25 \mu \mathrm{g} / \mathrm{dL}$ dikategorikan tinggi (Marianti, 2013). Timbal yang diabsorpsi oleh tubuh akan mengikat gugus aktif dari enzim ALAD (Amino Levulinic Acid Dehidrase), dimana enzim ini berfungsi pada sintesis sel darah merah. Adanya senyawa timbal akan mengganggu kerja enzim ini sehingga sintesa sel darah merah menjadi terganggu (Palar, 2008).

Beberapa gejala yang timbul akibat terpapar timbal secara kronis termasuk diantaranya adalah kehilangan libido, infertilitas laki-laki, gangguan menstruasi, serta aborsi spontan pada wanita. Pada laki-laki telah terbukti adanya perubahan dalam spermatogenesis. Hal ini juga senada dengan hasil penelitian dari Harianto Ludirdja tahun 1994 yang menyimpulkan bahwa pada polisi lalu lintas mempunyai jumlah spermatozoa $(19,5$ juta spermatozoa/ml) lebih rendah dari standar normal $(\geq 20 \mathrm{juta} / \mathrm{ml})$, gerakan spermatozoa $(44,5 \%)$ lebih rendah dari standar normal $(\geq 50 \%)$ dan bentuk spermatozoa normal (39,3\%) mempunyai nilai yang lebih rendah dari standar normal $(\geq 50 \%)$ dan timbal yang melewati plasenta pada wanita hamil yang terpapar timbal selama kehamilan dapat menyebabkan kematian akibat terpapar dan toksisitas (Riyadina, 1997).

Keracunan timbal dapat menyebabkan efek akut dan kronis. Keracunan akut yaitu akibat pemaparan yang terjadi dalam waktu yang relatif singkat (dapat terjadi dalam waktu 2-3 jam), dengan kadar yang relatif besar. Keracunan akut yang disebabkan oleh timbal biasanya terjadi karena kecelakaan misalnya, peledakan atau kebocoran yang tiba-tiba dari uap logam timbal, kerusakan sistem ventilasi di dalam ruangan. Keracunan akut ditandai oleh rasa terbakar pada mulut, terjadinya perangsangan dalam gastrointestinal, dan diikuti dengan diare. Keracunan kronis terjadi karena absorpsi timbal dalam jumlah kecil, tetapi dalam jangka waktu yang lama dan terakumulasi dalam tubuh. Gejala keracunan kronis ditandai oleh rasa mual, anemia, sakit di sekitar perut, dan dapat menyebabkan kelumpuhan. Organ-organ tubuh yang menjadi sasaran dari keracunan timbal adalah sistem peredaran darah, sistem saraf, sistem urinaria, sistem reproduksi, sistem endokrin, dan jantung (Palar, 2008).

Studi toksisitas timbal menunjukkan bahwa kandungan timbal dalam darah sebanyak $100 \mu \mathrm{g} / \mathrm{L}$ dianggap sebagai tingkat aktif (level action) berdampak pada gangguan perkembangan dan penyimpangan perilaku. Sedangkan kandungan timbal $450 \mu \mathrm{g} / \mathrm{L}$ membutuhkan perawatan segera dalam waktu 48 jam. Kandungan timbal lebih dari $700 \mu \mathrm{g} / \mathrm{L}$ menyebabkan kondisi gawat secara medis (medical emergency). Kandungan timbal di atas 
$1.200 \mu \mathrm{g} / \mathrm{L}$ bersifat sangat toksik dan dapat menimbulkan kematian. Pada anak, kadar timbal $68 \mu \mathrm{g} / \mathrm{L}$ dapat menyebabkan anak makin agresif, kurang konsentrasi, bahkan menyebabkan kanker. Pada anak, kadar keracunan timbal yang tinggi dapat menyebabkan anemia, kerusakan otak, hati, ginjal, saraf dan pencernaan, koma, kejang-kejang atau epilepsi, serta dapat menyebabkan kematian (Naria, 2005).

Berdasarkan penelitian yang telah dilakukan dengan bioindikator rambut bahwa dengan uji signifikan dan regresi linier terdapat korelasi positif antara lama bekerja dengan kandungan timbal dalam rambut pekerja, khususnya pekerja SPBU (Subagiada, 2011).

Dari latar belakang di atas maka perlu dilakukan Penelitian kadar timbal pada rambut pekerja bengkel tambal ban, dan ikan Mas yang dipelihara dalam kolam di pinggir jalan Soekarno-Hatta Bandar Lampung.

Rumusan masalah dalam penelitian ini adalah apakah rambut pekerja bengkel tambal ban dan daging ikan Mas di pinggir jalan Soekarno-Hatta Bandar Lampung telah terpapar logam berat timbal $(\mathrm{Pb})$ dan apakah kadarnya masih di bawah batas ambang.

Penelitian ini bertujuan untuk menganalisis kadar timbal pada rambut pekerja bengkel tambal ban dan daging ikan Mas yang dipelihara di pinggir jalan Soekarno-Hatta Bandar Lampung.

Penelitian ini diharapkan dapat mengetahui dan memberikan informasi kepada masyarakat kadar logam berat timbal $(\mathrm{Pb})$ pada manusia, ikan dan tanaman yang ada di Jalan TranSumatera.

\section{METODE PENELITIAN}

Penelitian ini telah dilaksanakan di Laboratorium Kesehatan Daerah Bandar Lampung dan Laboratorium Fakultas MIPA Universitas Lampung pada tahun 2016 dengan secara spektrofotometri serapan atom.

Peralatan yang digunakan dalam penelitian ini adalah berupa gunting rambut, sisir, piasau, kantong plastik, kertas label, kertas saring, Erlenmeyer $100 \mathrm{ml}$, gelas piala $100 \mathrm{ml}$, pinset, spatula, pengaduk kaca, tabung reaksi, labu takar $50 \mathrm{ml}$, labu takar $100 \mathrm{ml}$, pipet tetes, oven $105^{\circ} \mathrm{C}$, timbangan elektrik, hot plate dan Atomic Absorbtion Spectrophotometer (AAS), dan Spektrofotometri UV-Vis.

Bahan yang digunakan pada penelitian ini adalah rambut, ikan mas, aseton teknis, aseton pro analyse, aquades, asam nitrat $\left(\mathrm{HNO}_{3}\right)$, asam sulfat pekat $\left(\mathrm{H}_{2} \mathrm{SO}_{4}\right) \mathrm{p}$, larutan timbal, dan asam perklorat $\left(\mathrm{HClO}_{4}\right)$.

Teknik pengambilan sampel dilakukan secara acak atau random. Pengambilan sampel rambut 20 orang pekerja bengkel tambal ban. Sampel dikelompokan menjadi 4 kelompok berdasarkan lama kerja, yaitu: 0-3 tahun, 3-6 tahun, 6-9 tahun, 9-12 tahun. Masing-masing kelompok 5 ulangan. Sampel rambut dimasukan ke dalam gelas piala $100 \mathrm{ml}$, direndam dengan 10 $\mathrm{ml}$ aseton teknis selama 15 menit sambil diaduk dengan pengaduk kaca, selanjutnya dibilas menggunakan aquades. Sampel selanjutnya direndam dalam $10 \mathrm{ml}$ aseton pro analyse, selama 15 menit sambil diaduk. Sampel ditiriskan, selanjutnya dibungkus kertas saring yang telah diketahui bobot keringnya. Sampel dalam kertas saring dikeringkan dalam oven $105^{\circ} \mathrm{C}$ selama 2 jam, dimasukan kedalam eksikator selama 10 menit. Sampel rambut yang telah dikeringkan ditimbang bersama dengan kertas saring pembungkusnya untuk memperoleh bobot keringnya (Ashraf et al., 1995).

Sampel rambut yang diketahui bobot keringnya dimasukan ke dalam Erlenmeyer 100 $\mathrm{ml}$ kemudian ditambah $5 \mathrm{ml} \mathrm{HNO}_{3}$ dan dibiarkan selama \pm 1 jam. Sampel dipanaskan $\pm 4-6$ jam menggunakan hot plate pada skala suhu $110^{\circ} \mathrm{C}$, didinginkan dan ditambahkan $0,4 \quad \mathrm{ml}_{2} \quad \mathrm{H}_{2} \mathrm{SO}_{4}$ pekat, dipanaskan kembali \pm 1 jam. Larutan campuran $\mathrm{HNO}_{3}$ dan $\mathrm{HClO}_{4}$ (1:2) ditambahkan sebanyak 2 tetes kedalam sampel pada saat terjadi perubahan warna dari coklat menjadi kuning bening. Kemudian larutan dipanaskan kembali selama 15 menit. Larutan kemudian dijadikan $50 \mathrm{ml}$ untuk sampel rambut (Reitz et al., 1960).

Sampel ikan mas diperoleh dari tiga kolam secara acak, dibersikan kemudian diambil daging dan insangnya. Masing-masing sampel ditimbang \pm 5 gram kemudian dikeringkan dalam open $110^{\circ} \mathrm{C}$ selama satu malam. Sampel diambil dilarutkan dengan campuran $\mathrm{HNO}_{3}: \mathrm{HClO}_{4}(1: 1)$ sebanyak $3 \mathrm{ml}$, dan direndam selama satu malam, setelah itu dipanaskan dalam water bath dengan suhu $100{ }^{\circ} \mathrm{C}$ selama 5 jam kemudian diencerkan sampai volume $10 \mathrm{ml}$. Selanjutnya pasingmasing sampel dikeringkan lalu didestruksi dengan petrolium eter dalam tanur sampai suhu $350{ }^{\circ} \mathrm{C}$ sampel tidak boleh terbakar dan diabukan selama satu malam. Abu dilarutkan dalam $5 \mathrm{ml}$ $\mathrm{HNO}_{3} 1 \mathrm{~N}$ saring dan residunya diencerkan hingga volume $50 \mathrm{ml}$.

Siapkan 7 buah labu takar $100 \mathrm{ml}$, kemudian masing-masing diisi $0,5 \mathrm{ml}, 1 \mathrm{ml}, 2 \mathrm{ml}, 5 \mathrm{ml}, 10$ $\mathrm{ml}, 20 \mathrm{ml}$ dan $40 \mathrm{ml}$ larutan standar $10 \mathrm{ppm}$ dan tambahkan aquadest sampai tanda tera sehingga 
diperoleh kadar timbal 0,$05 ; 0,1 ; 0,2 ; 0,5 ; 1 ; 2 ; 4$ (ppm).

Penentuan panjang gelombang maksimum dengan pengukuran serapan menggunakan larutan standar. Selanjutanya ukur serapan untuk menentukan panjang gelombang maksimum pada range daerah panjang gelombang $283,3 \mathrm{~nm}$ dan tentukan panjang gelombang maksimum dengan menggunakan kurva hubungan serapan dan panjang gelombang (SNI, 2005).

Alat spektrofotometri serapan atom diatur dan dioptimalkan dengan menekan tombol start ikuti petunjuk penggunaan alat yang tertera pada monitor. Selanjutnya larutan seri standar diukur satu per satu dengan spektrofotometri serapan atom melalui pipa kapiler, kemudian dibaca dan dicatat masing-masing serapannya (absorban). Lalu kurva kalibrasi berdasar data-data yang telah diperoleh dan ditentukan persamaan garis lurusnya $\mathrm{Y}=\mathrm{bx}+\mathrm{a}$.

Masing-masing sampel hasil dari pengabuan basah dimasukan ke dalam viret yang siap dianalisis. Masing-masing sampel dilakukan pengulangan sebanyak 3 kali. Hasil pengukuran absorbansi masing-masing sampel, ditentukan kadar timbal dengan persamaan regresi linier di atas.

\section{HASIL}

Spektrofotometer serapan atom yang telah distandarisasi yaitu : Element : $\mathrm{Pb}$, Wavelength (nm): 283,3, Peak (nm) : 283,3, Lamp Current Low (mA): 10, Slit Width (nm): 0,7, Lamp Mode: BGC-D2

Kurva kalibrasi diperoleh dengan mengukur absorbansi dari beberapa konsentrasi larutan standar timbal dengan panjang gelombang 283,3 $\mathrm{nm}$. Hasil yang diperoleh dapat dillihat pada Tabel 1.

Tabel 1. Hasil Pengukuran Absorbansi Larutan Standar Timbal (Pb)

\begin{tabular}{cc}
\hline $\begin{array}{c}\text { Konsentrasi } \\
\text { Standar Timbal (ppm) }\end{array}$ & Absorbansi \\
\hline 1 & 0,0012 \\
\hline 2 & 0,0098 \\
\hline 4 & 0,0310 \\
\hline
\end{tabular}

Hasil pengukuran absorbansi selanjutnya digunakan untuk membuat kurva kalibrasi, seperti terlihat pada Gambar 1 di bawah ini :

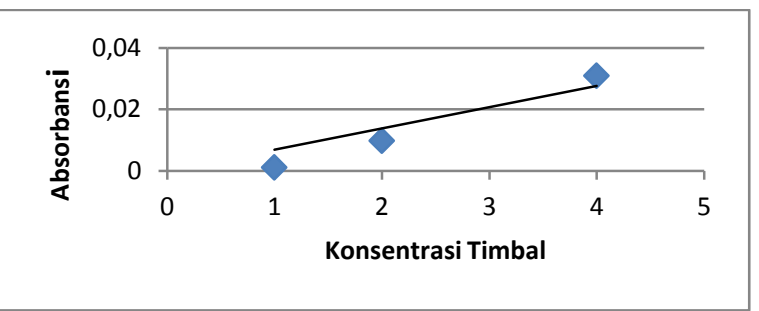

Gambar 1. Kurva Kalibrasi Larutan Standar Timbal (Pb)

Berdasarkan data kurva kalibrasi di atas, diperoleh nilai r (koefesien korelasi) yaitu 0,999. Dengan persamaan regresi untuk larutan standar timbal, yaitu :

\begin{tabular}{ll|}
\cline { 2 - 2 } & $\mathbf{y = 0 , 0 1 0 0 x}-\mathbf{0 , 0 0 9 3 3}$ \\
Dimana : & $=$ absorbansi / serapan \\
$\mathrm{y}$ & $=$ konsentrasi \\
$\mathrm{x}$ & $=0,0100$ \\
Slope & $=-0,00933$ \\
Intersep &
\end{tabular}

Koefisien korelasi $\left(\mathrm{r}_{\mathrm{xy}}\right)$ adalah sebesar 0,999 . Hubungan antara $\mathrm{y}$ dan $\mathrm{x}$ membentuk garis lurus ditunjukan dengan nilai $\left(r_{x y}\right)$ mendekati atau sama dengan satu. Hasil perhitungan persamaan garis linier larutan standar timbal dapat dilihat pada Lampiran E.

Hasil pengukuran rata-rata kadar timbal pada rambut dan ikan mas dapat dilihat pada Tabel 4.2 dan 4.3

Tabel 2. Kadar Rerata Timbal dalam Rambut Pekerja Tambal Ban

\begin{tabular}{ll}
\hline $\begin{array}{c}\text { Lama Kerja } \\
\text { (Tahun) }\end{array}$ & $\begin{array}{l}\text { Rerata Kadar } \\
\text { Timbal (ppm) }\end{array}$ \\
\hline $0-3$ & 1,296 \\
\hline $3-6$ & 1,798 \\
\hline $6-9$ & 0,966 \\
\hline $9-12$ & 1,172 \\
\hline
\end{tabular}

Tabel 3. Kadar Rerata Timbal dalam Ikan Mas pada Masing-masing Kolam

\begin{tabular}{ccc}
\hline \multirow{2}{*}{ Kolam } & \multicolumn{2}{c}{$\begin{array}{c}\text { Rerata kadar timball } \\
\text { (ppm) }\end{array}$} \\
\cline { 2 - 3 } & insang & daging \\
\hline I & 0,12772 & 0,0539 \\
\hline II & 0,15878 & 0,1160 \\
\hline III & 0,11636 & 0,0539 \\
\hline
\end{tabular}

\section{PEMBAHASAN}

Pemilihan lokasi pengambilan sampel rambut dan ikan mas disepanjang jalan Soekarno-Hatta Bandar Lampung, karena disana merupakan jalan lalu lintas utama kendaraan. 
Selain itu, populasi kendaraan berjumlah cukup besar sehingga memungkinkan pencemaran udara dan air meningkat.

Sampel harus berupa larutan, maka rambut dan ikan sebelumnya dilakukan destruksi terlebih dahulu. Fungsi dari destruksi adalah memutus ikatan antara senyawa organik dengan logam yang akan dianalisis (Hidayati, 2013).

Dalam penelitian ini menggunakan destruksi basah karena pada umumnya destruksi basah dapat dipakai untuk menentukan unsurunsur dengan konsentrasi rendah. Setelah proses destruksi diharapkan yang tertinggal hanya logam-logam saja dalam bentuk ion. Pelarut yang digunakan dalam metode ini antara lain asam nitrat $\left(\mathrm{HNO}_{3}\right)$, asam sulfat $\left(\mathrm{H}_{2} \mathrm{SO}_{4}\right)$ dan asam perklorat $\left(\mathrm{HClO}_{4}\right)$ (Hidayati, 2013).

Menurut Reitz et al. (1960) destruksi dilakukan menggunakan menggunakan asam nitrat $\left(\mathrm{HNO}_{3}\right)$, asam sulfat $\left(\mathrm{H}_{2} \mathrm{SO}_{4}\right)$ dan asam perklorat $\left(\mathrm{HClO}_{4}\right)$. Larutan kemudian dijadikan 50 $\mathrm{ml}$ dengan menggunakan aquadest sehingga diperoleh larutan jernih kekuningan. Penambahan masing-masing asam mempunyai tujuan tersendiri. Pada metode pertama menggunakan asam nitrat $\left(\mathrm{HNO}_{3}\right)$ sebagai agen pengoksidasi utama, karena asam nitrat $\left(\mathrm{HNO}_{3}\right)$ merupakan pelarut logam yang baik, timbal teroksidasi oleh asam nitrat $\left(\mathrm{HNO}_{3}\right)$ sehingga menjadi larut.

$3 \mathrm{~Pb}+8 \mathrm{HNO}_{3 \text { (aq) }} \longrightarrow 3 \mathrm{~Pb}^{2+}$ (aq) $+6 \mathrm{NO}_{3}^{-}+2 \mathrm{NO}_{(\mathrm{g})}+$ $4 \mathrm{H}_{2} \mathrm{O}_{(\mathrm{I})}$

Sedangkan asam sulfat $\left(\mathrm{H}_{2} \mathrm{SO}_{4}\right)$ adalah sebagai katalis untuk mempercepat reaksi terputusnya timbal dari senyawa organik yang ada dalam sampel rambut. Asam sulfat $\left(\mathrm{H}_{2} \mathrm{SO}_{4}\right)$ merupakan katalis yang mempengaruhi lingkungan sehingga katalis ini tidak ikut bereaksi. Sementara itu, asam perklorat $\left(\mathrm{HClO}_{4}\right)$ bertindak sebagai oksidator untuk membantu asam nitrat $\left(\mathrm{HNO}_{3}\right)$ mendekomposisi matriks organik (Hidayati, 2013).

Pada metode kedua asam nitrat $\left(\mathrm{HNO}_{3}\right)$ dikombinasikan dengan asam perklorat $\left(\mathrm{HClO}_{4}\right)$ sebagai campuran asam untuk mendestruksi, dimana asam perklorat $\left(\mathrm{HClO}_{4}\right)$ bertindak sebagai oksidator yang kuat untuk membantu asam nitrat $\left(\mathrm{HNO}_{3}\right)$ mendekomposisi matriks organik rambut. Sehingga rambut dan daging ikan dapat larut dengan sempurna. Setelah sampel rambut didestruksi kemudian dilakuan analisis kadar timbal menggunakan spektrofotometer serapan atom dengan panjang gelombang 283,3 nm (Hidayati, 2013).

Sebelum melakukan analisis suatu unsur dalam sampel terlebih dahulu harus membuat kurva standar yang berfungsi untuk mengetahui hubungan antara konsentrasi larutan dengan absorbansinya sehingga konsentrasi sampel dapat diketahui. Dari percobaan yang telah dilakukan didapat persamaan regresi linier sebagai berikut :

$$
\mathbf{y}=\mathbf{0 , 0 1 0 0 x}-\mathbf{0 , 0 0 9 3 3}
$$

sehingga koefisien korelasi yang diperoleh adalah 0,999 . Sedangkan nilai koefisien korelasi yang baik adalah mendekati 1 per tanda berbentuk garis lurus.

Berdasarkan data hasil penelitian dengan menggunakan persamaan regresi linier kurva standar, maka perhitungan kadar sampel kemudian dilakukan dan diperoleh hasil yang menunjukan bahwa kadar timbal dalam rambut pekerja bengkel tambal ban pada kisaran minimal $0,258 \mathrm{ppm}$ dan maksimum 4,813 ppm, sedang pada isang ikan 0,11636 sampai 0,15878 dan pada daging ikan 0,0539 samapai 0,1160 seperti ditujukan Tabel 4.2 dan 4.3. Pengelompokan lama bekerja dilakukan untuk mempermudah analisis pengaruh dengan lama bekerja kadar timbal pada rambut pekerja bengkel tambal ban.

Setelah dilakukan analisis dengan menggunakan uji ANOVA, diperoleh hasil Fhit < Ftabel. Hal ini berarti tidak ada hubungan signifikan antara lama bekerja dengan kadar timbal pada rambut bagi pekerja bengkel tambal ban di sepanjang jalan Soekarno-Hatta. Jika dibandingkan dengan hasil penelitian yang dilakukan oleh Kadek Subagiada (2011) analisis kadar timbal pada pekerja SPBU di kota Samarinda yang mencapai konsentrasi 10 ppm sesungguhnya cukup tinggi dan telah ada pengaruh signifikan dengan lama bekerja dibanding kadar timbal pada rambut pekerja bengkel tambal ban di sepanjang jalan SoekarnoHatta Bandar Lampung. Meningkatnya kadar timbal dalam tubuh pekerja SPBU, karena SPBU memiliki resiko cukup tinggi untuk terpapar emisi buangan kendaraan bermotor. Hal ini, karena lamanya interaksi pekerja SPBU dengan bahan yang mempunyai kandungan timbal menyebabkan makin banyak terjadinya akumulasi logam berat timbal di dalam tubuh melalui pernafasan secara langsung (Subagiada, 2011).

Berdasarkan dengan lama bekerja tidak ada hubungan signifikan, hal ini disebabkan tempat tidak homogen, karena di jalan SoekarnoHatta ada jalan yang menanjak ada yang datar dan tidak semua kendaraan berhenti. Sedangan di SPBU paparan mendatar dan banyak kendaraan berhenti. Selain itu, pekerja sebelum bekerja sebagai bengkel tambal ban di jalan Soekarno-Hatta sebelumnya ditempat lain bekerja. Lama bekerja 3-6 tahun kadar timbal 
lebih tinggi, yaitu dengan lama bekerja 3 tahun kadar timbal 4,813 ppm. Pada dareah tersebut besar kendaraan lebih banyak berhenti ditempat lokasi dan waktu bekerja cukup lama, di banding lama bekerja bengkel tambal ban yang lain, kadar timbal lebih rendah karena kendaraan banyak, tetapi kurang berhenti dilokasi dan jam kerja sedikit sehingga kadar timbal rendah (Subagiada, 2011).

Kadar timbal pada rambut pekerja bengkel tambal ban dapat dinyatakan bahwa responden telah terkontaminasi timbal dalam tingkatan rendah. Faktor yang mempengaruhi akumulasi timbal pada tubuh seseorang yaitu umur, pada orang dewasa lebih rendah dari pada anak-anak, karena sistem imun orang dewasa telah terbentuk sempurna dibandingkan anak-anak. Lama terpapar juga mempengaruhi konsentrasi timbal masuk ke dalam tubuh. Lama terpapar merupakan waktu terpapar seseorang dengan timbal. Emisi gas buang kendaraan dengan bahan bakar bertimbal yang terhirup setiap harinya oleh seseorang saat berada diruang terbuka sangat mendorong meningkatnya konsentrasi timbal dalam tubuh. Selain itu, lokasi tempat tinggal akan mempengaruhi konsentrasi timbal yang masuk dalam tubuh. Hal ini karena semakin dekatnya jarak rumah dengan jalan berarti semakin dekat dengan asap kendaraan yang memungkinkan semakin tinggi kadar timbal di udara.

Kadar timbal pada insang ikan mas lebih tinggi dibandingkan pada dagingnya hal ini sesuai dengan proses fisiologi pada tubuh ikan yaitu proses masuknya timbal bersama dengan air yang secara difusi diserap oleh insang selanjunya disebar ke seluruh tubuh melalui darah sehingga terjadi penimbunan timbal pada daging ikan mas (Darmono, 2001).

Dari hasil analisis ANOVA sampel daging ikan mas pada ketiga kolam $\mathrm{F}$ hitung lebih kecil dari $\mathrm{F}$ table $(5 \%)$ ini berarti tidak ada perbedaan signifikan antar kolam. Sedangkan pada sampel insang diperoleh $\mathrm{F}$ hitung lebih besar dari $\mathrm{F}$ Tabel (5\%) ini berarti terdapat perbedaan

\section{DAFTAR PUSTAKA}

Ardyanto D. 2005. Deteksi Pencemaran Timah Hitam $(\mathrm{Pb})$ dalam Darah Masyarakat yang Terpajan Timbal (Plumbum). Kesehatan Lingkungan, 2:67-76.

Ashraf W, Jaffar M, Anwer K, Ehsan U. 1995. Age-and sex-based Comparative Distribution of Selected Metals in the signifikan kadar timbal pada insang ikan mas antar kolam.

Setiap manusia mempunyai daya tahan yang berbeda terhadap toksisitas timbal. Biasanya orang yang mengkonsumsi timbal sekitar 0,2-2,0 $\mathrm{mg} / \mathrm{hari}$ akan mengalami keracunan dan pada orang dewasa timbal diserap melalui usus sekitar 5-10\%. Intake timbal 2,5 $\mathrm{mg} /$ hari akan memerlukan waktu hampir 4 tahun untuk menjadi toksik, dan hal itu terjadi pada waktu timbal terakumulasi dalam jaringan lunak. Sedangkan intake timbal 3,5 mg/hari akan mengakibatkan kandungan timbal yang toksik dalam beberapa bulan saja (Darmono, 1995).

Pada keracunan akut biasanya terjadi karena masuknya senyawa timbal yang larut dalam asam atau menghirup uap timbal tersebut. Gejala-gejala yang timbul berupa mual, muntah, sakit perut hebat, kelainan fungsi otak, anemia berat, kerusakan ginjal bahkan kematian dapat terjadi dalam 1-2 hari (Darmono, 1995).

Pada pekerja bengkel tambal ban di sepanjang jalan Soekarno-Hatta Bandar Lampung kadar timbal masih dalam batas rendah sehingga tidak menyebabkan keracunan, baik keracunan secara akut maupun kronis.

\section{SIMPULAN}

Berdasarkan hasil penelitian yang telah dilakukan bahwa pekerja bengkel tambal ban di jalan Soekarno-Hatta Bandar Lampung menunjukan adanya cemaran timbal pada rambut pekerja dengan minimal 0,258 ppm dan maksimal 4,813 ppm. Pada insang ikan mas 0,11636 sampai 0,15878 ppm sedang pada dagingnya 0,0539 sampai $0,1160 \mathrm{ppm}$.

\section{SARAN}

Untuk dilakukan penelitian lebih lanjut dengan bioindikator tanaman dan hewan lain yang ada di Jalan Trans-Sumatera Bandar Lampung.

Scalp Hair of an Urban Population from Two Cities in Pakistan. Environ Pollut 87:61-64.

Darmono. 1995. Logam dalam Sistem Biologi. Jakarta: Universitas Indonesia Press.

Darmono. 2001. Lingkungan Hidup dan Pencemaran, Hubungan Dengan 
Toksilogi Senyawa Logam. Jakarta: Universitas Indonesia Press.

Darmono. 2009. Lingkungan Hidup dan Pencemaran. Jakarta: Universitas Indonesia Press.

Harianto Ludirdja. 1994. Pengaruh Timbal dari Emisi Kendaraan Bermotor Terhadap Kualitas Semen (Air Mani) Polisi Lalu Lintas Jakarta. Tesis S2, Program Pasca Sarjana UI, Program Studi Kesehatan dan Keselamatan Kerja, Jakarta.

Hidayati, Nur Ervina. 2013. Perbandingan Metode Destruksi pada Analisis Pb dalam Rambut dengan AAS. Jurusan FMIPA, Universitas Negeri Semarang.

Marianti, Adytia dan Tri Prasetya Agung. 2013. Rambut sebagai Bioindikator Pencemaran Timbal pada Penduduk di Kecamatan Semarang Utara. Jurusan Biologi dan Kimia FMIPA, UNNES Semarang.

Naria, Evi. 2005. Mewaspadai Dampak Bahan Pencemar Timbal $(\mathrm{Pb})$ di Lingkungan Terhadap Kesehatan. Fakultas Kesehatan Masyarakat. USU.
Palar, Heryando. 2008. Pencemaran dan Toksikologi Logam Berat. Jakarta: Rineka Cipta. 74-93.

Petrucci RH. 1982. General Chemistry. McMillan Publ, Co, Inc, New York.

Reitz, L. L., Smith, W. H., and Plumlee, M. P. 1960. A Simple Wet Oxidation Precedure For Biological Materials. Anal Chem 32: 1728.

Riyadina, Woro. 1997. Pengaruh Pencemaran $\mathrm{Pb}$ (Plumbum) Terhadap Kesehatan" Badan Penelitian dan Pengembangan. Kesehatan Depkes RI.

Standar Nasional Indonesia 189-7119.4-2005. 2005. Cara Uji Kadar Timbal $(P b)$ dengan Metode Destruksi Basah Menggunakan Spektrofotometer Serapan Atom.

Subagiada, Kadek. 2011. Penentuan Kadar Timbal $(\mathrm{Pb})$ dengan Bioindikator Rambut pada Pekerja SPBU Di kota Samarinda. Skripsi. Jurusan Fisika FMIPA, Universitas Mulawarman.

Sudarmaji, J. Mukono, Corie I.P. 2006. Toksikologi Logam Berat B3 dan dampaknya Terhadap Kesehatan. Jurnal Kesehatan Lingkungan, Vol. 2, No.2. 